K A N D A I

\begin{tabular}{|l|l|r|}
\hline Volume 17 & No. 1, Mei 2021 & Halaman 45-59 \\
\hline
\end{tabular}

\title{
DIKSI DALAM WACANA HUMOR INDONESIA DI MEDIA SOSIAL (Diction in Indonesia Humor Discourse on Sosial Media)
}

\author{
Hari Kusmanto, Atiqa Sabardila, \& Ali Imron Al-Ma'ruf \\ Universitas Muhammadiyah Surakarta \\ Jalan A Yani Tromol Pos 1, Kartasura, Surakarta, Indonesia \\ Pos-el: harikusmanto.ums@gmail.com, as193@ums.ac.id, ali.imron@ums.ac.id \\ (Diterima: 12 Februari 2020; Direvisi: 22 September 2020; Disetujui: 11 April 2021)
}

\begin{abstract}
This study aims to describe diction in the discourse of humor on Facebook social media. This research approach is descriptive qualitative. The data of this study are diction in the discourse of humor on Facebook social media. The data source is in the form of humorous discourse on Facebook social media. The research data was collected using the documentation and listening method and continued with the note-taking technique. The data of this study were analyzed using translational equivalent methods and marking reading techniques. The results of this study indicate the use of diction in Indonesian humor discourse on social media including (1) daily diction; (2) absorption words (Javanese and English); (3) greetings; (4) connotative words; (5) concrete words; and (6) vulgar words. Daily diction in Indonesian humorous discourse is the most common diction. This finding shows that daily diction in humorous discourse serves to establish intimacy in communication.
\end{abstract}

Keywords: diction, humor, social media, Facebook

Abstrak

Penelitian ini bertujuan mendeskripsikan diksi dalam wacana humor di media sosial facebook. Pendekatan penelitian ini adalah deskriptif kualitatif. Data-data penelitian ini adalah diksi dalam wacana humor di media sosial facebook. Sumber datanya berupa wacana humor di media sosial facebook. Data penelitian ini dikumpulkan dengan menggunakan metode dokumentasi dan simak serta dilanjutkan dengan teknik catat. Data penelitian ini dianalisis dengan menggunakan metode padan translasional dan teknik baca markah. Hasil penelitian ini menunjukkan penggunaan diksi pada wacana humor Indonesia di media sosial meliputi: (1) diksi sehari-hari; (2) kata serapan (Jawa dan Inggris); (3) kata sapaan; (4) kata konotatif; (5) kata konkret; dan (6) kata vulgar. Diksi sehari-hari dalam wacana humor Indonesia merupakan diksi yang paling banyak ditemukan. Temuan ini menunjukkan bahwa diksi keseharian dalam wacana humor berfungsi untuk menjalin keakraban dalam berkomunikasi.

Kata-kata kunci: diksi, humor, media sosial, Facebook

DOI: $10.26499 / j k . v 17 i 1.2186$

How to cite: Kusmanto, H., Sabardila, A., \& Al-Ma'ruf, A. I. (2021). Diksi dalam wacana humor Indonesia di media sosial. Kandai, 17(1), 45-59 (DOI: 10.26499/jk.v17i1.2186)

\section{PENDAHULUAN}

Humor dalam masyarakat modern menjadi bagian kehidupan yang tidak dapat dipisahkan dari kehidupan. Setiap orang mengenal humor yang bahkan menggunakan humor dalam berkomunikasi, khususnya dalam situasi santai. Humor sebagai salah satu fenomena kebahasaan yang ditemukan di berbagai tempat dan tradisi masyarakat di Indonesia. Salah satunya adalah humor yang ditemukan di media sosial facebook. Humor di media sosial sebagai 
salah satu fenemona kebahasaan yang menarik untuk dikaji secara ilmiah. Hal ini dikarenakan wacana humor di media sosial tidak hanya menyajikan lelucon, tetapi juga menyajikan beragam ide, gagasan, dan kritik yang ingin disampaikan oleh penutur.

Masyarakat memanfaatkan humor untuk menyampaikan ide, gagasan, dan kritik. Berdasarkan hasil pembacaan terhadap beberapa wacana humor di media sosial facebook (Surga Humor, Humor Lalu Lalang, Humor Indonesia Bersatu, Kementerian Humor, Humor, Humor Indonesia, dan Curahan Perasaan dan Humor), diketahui bahwa bahasa humor yang dipakai telah memanfaatkan beragam diksi. Humor di media sosial facebook (Surga Humor, Humor Lalu Lalang, Humor Indonesia Bersatu, Kementerian Humor, Humor, Humor Indonesia, dan Curahan Perasaan dan Humor) memiliki kualitas, baik dari sarana bahasanya maupun kandungan nilainya. Bahkan, humor di media sosial sebagai cermin dari situasi dan kondisi sosial pencipta humor, seperti situasi sosial, politik, ekonomi, agama, budaya, dan sebagainya.

Diksi dalam wacana humor memiliki peran penting dalam membangun makna dan estetika humor di media sosial. Pemilihan kata dalam wacana humor di media sosial perlu mempertimbangkan kesesuaian dengan aspek makna yang ditimbulkan. Selain aspek makna, pemilihan kata dalam wacana humor di media sosial juga mempertimbangkan aspek estetika humor atau keindahan bahasa humor.

humor telah dilakukan peneliti sebelumnya, berikut ini penelitian terdahulu yang berkaitan dengan humor. Saputro (2016) menemukan tindak tutur ilokusi mengejek, memerintah, mengeluh, menyindir pada humor Mu'Ammar Al-Qazafi. Hasil Penelitian Bowman \& Hallett (2017) menyimpulkan pendengar humor tidak terbuka kritik diri melalui kritik lucu. Hasil penelitian Wijana (2018) menemukan banyak tindak tutur, prasangka, dan implikasi pragmatis pada wacana humor Indonesia untuk menciptakan kegiatan. Penelitian Deen (2018) menyimpulkan humor politik mendorong niat baik terhadap sesama warga negara, menyadarkan akan batasbatas kekuasaan, dan mampu membuat diri sendiri tidak terlalu serius. Setiyanto (2018) menemukan pelanggaran maksim kualitas, cara, dan relevansi pada humor lalu lintas.

Penelitian yang berkaitan tentang media sosial sebagai penyampai humor telah dilakukan peneliti sebelumnya, Bhakti et al. (2018) meneliti gerakan sosial politik meme pada media sosial instagram untuk Bali tolak reklamasi. Simpulannya, penyampaian meme melalui akun instagram menjadi cara yang terbilang efektif dan ideal.

Penelitian yang berkaitan humor yang telah dilakukan peneliti terdahulu hanya berkaitan dengan aspek linguistik dan komunikatif, akan tetapi belum banyak yang meneliti berkaitan dengan sarana retorika humor, khususnya diksi. Guna mengisi kekurangan tersebut penelitian ini difokuskan pada penggalian diksi humor di media sosial, yakni diksi yang digunakan dalam wacana humor di media sosial facebook.

\section{LANDASAN TEORI}

Diksi merupakan pilihan kata yang digunakan untuk menyampaikan gagasan atau ide dengan memperhatikan aspek estetik bahasa. Melalui estetika tersebut diksi memiliki daya puitis (Menninghaus et al., 2017). Lebih lanjut Pradopo (1993) mengartikan diksi sebagai pilihan kata yang tepat dan selaras dalam penggunaanya untuk mengungkapkan gagasan seseorang sehingga timbul efek 
tertentu sesuai dengan apa yang diharapkan. Hal tersebut sesuai dengan yang dinyatakan Fatoni (2017) diksi sebagai suatu pilihan kata yang tepat dan selaras untuk mengungkapkan suatu gagasan sehingga gagasan dapat diterima oleh pendengar maupun pembaca.

Pendayagunaan diksi dalam wacana humor atau karya sastra haruslah mencakup tiga aspek yang berkaitan dengan diksi. Pertama, pemilihan kata yang tepat sesuai dengan gagasan yang disampaikan dan sesuai dengan situasi. Kedua, pilihan kata harus mampu membedakan nuansa makna untuk menemukan bentuk dan kecocokan situasi dan nilai rasa kelompok masyarakat pendengar. Ketiga, ketepatan dan kecocokan diksi hanya dimungkinkan dengan cara penguasaan kekayaan kosa kata (Keraf, 1987).

Karya sastra termasuk humor banyak mendayagunakan diksi untuk mencapai makna tertentu. (Al-Ma'ruf, 2012) menyatakan di antara diksi dalam karya sastra meliputi: kata konotatif, kata konkret, kata sapaan atau khas nama diri, kata seru khas Jawa, kata serapan, kata asing, kata arkais, kata vulgar, kata dengan objek realitas alam, dan kosakata bahasa daerah. Beberapa diksi tersebut juga terdapat dalam wacana humor Indonesia di media sosial facebook. Jenis-jenis diksi tersebut sebagai landasan untuk mengidentifikasi jenis diksi dalam wacana humor yang diteliti. Berikut ini dijelaskan masing-masing jenis diksi.

Kata konotatif adalah kata yang memiliki makna komunikatif yang terlepas dari makna referen atau kamus yang didasarkan pada pengetahuan atau perasaan pengarang. Lebih lanjut makna konotatif suatu kata memiliki keterkaitan antara budaya, konteks penggunaannya, pengalaman, prakiraan, emosi, pendidikan, dan pandangan mengenai dunia (Subet \& Zaid, 2018). Adapun berdasarkan jenisnya makna konotatif dapat dibedakan menjadi konotatif tinggi; konotatif berbahaya; konotatif tidak pantas; konotatif kasar; dan konotatif kanak-kanak (Shaumia, 2019).

Kata konkret adalah kata yang mengandung makna yang merujuk pada referen atau pengertian harfiah, sesuai dengan konvensi tertentu. Kata konkret merupakan kata yang merujuk pada benda konkret, seperti alam, hewan, benda, dan kata kerja yang merujuk pada tindakan (Borghesani \& Piazza, 2017). Akan tetapi, kata konkret sebenarnya tidak hanya terbatas pada hal tersebut.

Kata sapaan adalah kata yang berfungsi untuk menunjukkan orang atau sebagai penanda identitas seseorang. Sapaan dalam bermasyarakat memiliki peranan yang penting karena hal tersebut menentukan status sosial seseorang (Saleh, 2017). Kata sapaan dalam tindak komunikasi menunjukkan tingkat kesantunan berbahasa (Utama \& Arief, 2012). Kata sapaan dalam budaya tertentu dapat dibedakan berdasarkan faktor usia mitra tutur, kedudukan dalam keluarga, jenis kelamin, dan hubungan keluarga secara langsung (Suwija, 2018). Berdasarkan hal tersebut kata sapaan dalam tindak komunikasi berbahasa memiliki peran yang penting sebagai perwujudan tindak kesantunan berbahasa.

Kata serapan adalah kata-kata yang diambil atau dipungut dari bahasa lain, baik bahasa asing maupun bahasa daerah, baik secara utuh atau telah mengalami proses adaptasi ke dalam bahasa Indonesia. Selain itu kata serapan yang memiliki makna utuh atau sama seperti kata yang diacu maupun kata serapan yang memiliki makna sama. Akan tetapi, kata serapan biasanya telah mengalami perubahan makna dari kata aslinya (Wurianto, 2015).

Kata vulgar adalah kata yang dalam masyarakat intelek dipandang 
tabu untuk diucapkan atau digunakan dalam berkomunikasi dalam lingkungan masyarakat. Kata bermakna vulgar adalah kata yang memiliki nilai negatif sebagai lawan dari kata yang halus atau eufemisme (Sariah, 2018). Akan tetapi, apabila dicermati tidak semua kata vulgar memiliki konotasi yang jelek, bahkan tidak jarang kata yang dianggap vulgar berfungsi mempererat solidaritas. Akan tetapi, di antara pengguna kata vulgar tersebut telah ada kesepakatan atau konvensi.

Humor dalam masyarakat modern menjadi bagian yang tidak terpisahkan, hampir semua orang mengenal humor dan bahkan menggunakan humor dalam kehidupan sehari-hari. Humor dalam kehidupan sehari-hari mampu menjadi relaksasi menurunkan kejenuhan atau kebosanan seseorang. Hal ini sesuai dengan yang dinyatakan Budiyanto (2009) bahwa humor merupakan rangsangan yang mempunyai potensi untuk memancing orang untuk tertawa. Humor memiliki peran untuk membangun, mempromosikan, memperkuat, dan menyatukan komunikator (Rochmawati, 2017). Hal tersebut sesuai dengan karakteristik humor yang mencerminkan aspek peristiwa konyol, tidak biasa, kontradiktif, atau membuat orang tertawa (Ucan, 2018). Lebih lanjut humor berfungsi menambah kebahagiaan dan kesenangan untuk hidup dan mempromosikan sikap positif terhadap kehidupan (Dai, 2018).

Berdasarkan hal tersebut sebenarnya humor tidak hanya sebuah wacana yang menimbulkan rasa tawa kepada pemakainya. Bahkan lebih lanjut humor dijadikan sebagai sarana untuk membangun komunikasi yang efektif, efisien, dan berdaya kesantunan berkomunikasi. Oleh karena itu, humor juga mendayagunakan diksi untuk membangun humor yang berkualitas.
Berdasarkan uraian yang telah disajikan di atas permasalahannya adalah bagaimanakah humor di media sosial mendayagunakan diksi untuk menyampaikan gagasan kepada pembaca. Media sosial sebagai media proses perolehan, pengolahan, dan penyebaran ide, gagasan, kritik, dan informasi. Oleh karena itu, penelitian ini akan menggali pendayagunaan diksi dalam wacana humor di media sosial facebook.

\section{METODE PENELITIAN}

Pendekatan utama penelitian ini berbentuk deskriptif kualitatif (Creswell, 2014; Tojo \& Takagi, 2017; Zurqoni, Retnawati, Apino, \& Anazifa, 2019). Pendekatan deskriptif kualitatif dalam penelitian ini digunakan untuk menghasilkan generalisasi teoritis atau kaidah berupa diksi atau pilihan kata dalam humor di media sosial facebook. Sesuai dengan metode deskriptif kualitatif, data penelitian ini adalah diksi dalam wacana humor di media sosial facebook. Data yang digunakan dalam penelitian ini sejumlah 50 wacana humor. Data penelitian ini dikumpulkan pada bulan September sampai dengan Desember 2019. Wacana humor yang dipilih dalam penelitian ini adalah yang memiliki nilai pendidikan karakter. Sumber datanya berupa wacana humor di media sosial facebook. Pengumpulan data penelitian ini menggunakan metode dokumentasi dan simak serta dilanjutkan dengan teknik catat. Dokumentasi yang dimaksud adalah wacana humor di media sosial facebook. Metode simak dilakukan dengan cara peneliti membaca wacana humor secara cermat untuk mengidentifikasi jenis diksi yang digunakan dalam wacana humor. Selanjutnya, setelah data teridentifikasi dilakukan pencatatan data pada kartu data sesuai dengan jenis diksi yang 
ditemukan dalam wacana humor di media sosial facebook. Analisis data penelitian ini menggunakan metode padan translansional dan teknik baca markah (Sudaryanto, 2015). Metode padan translansional adalah metode analisis bahasa yang alat penentunya adalah bahasa atau lingual lain. Metode padan translansional digunakan untuk mengidentifikasi diksi pada wacana humor di media sosial facebook. Keabsahan data penelitian ini menggunakan trianggulasi teori mengingat data dalam penelitian ini adalah wacana humor. Dengan demikian, untuk menentukan suatu data wacana humor atau bukan diperlukan beberapa teori tentang humor dari beberapa pakar atau penelitian lain yang meneliti humor.

\section{PEMBAHASAN}

Hasil dan pembahasan penelitian berikut ini difokuskan pada deskripsi diksi dalam wacana humor Indonesia di media sosial facebook.

\section{Diksi dalam Wacana Humor}

Diksi dalam wacana humor Indonesia di media sosial facebook dapat dikelompokkan menjadi enam bentuk. Keenam bentuk diksi tersebut adalah (1) diksi sehari-hari; (2) kata serapan (Jawa, dan Inggris) hal tersebut muncul karena bahasa yang digunakan dalam wacana humor adalah bahasa Indonesia; (3) kata sapaan; (4) kata konotatif; (5) kata konkret; dan (6) kata vulgar. Diksi sehari-hari dalam wacana humor Indonesia merupakan diksi yang paling banyak ditemukan. Temuan ini menunjukkan bahwa diksi keseharian dalam wacana humor berfungsi untuk menyampaikan pesan kepada mitra wicara. Adapun daya kejutan diksi dalam wacana humor digantikan dengan konteks wacana humor. Temuan ini disajikan pada tabel 1.

Tabel 1. Persentase Diksi Wacana Humor Indonesia di Media Sosial Facebook

\begin{tabular}{|c|c|c|}
\hline No & Jenis Diksi & Persentase \\
\hline 1. & Kata sehari-hari & $38 \%$ \\
\hline 2. & Kata serapan & $22 \%$ \\
\hline 3. & Kata sapaan & $16 \% \%$ \\
\hline 4. & Kata konotatif & $12 \%$ \\
\hline 5. & Kata konkret & $8 \%$ \\
\hline \multirow[t]{2}{*}{6.} & Kata vulgar & $4 \%$ \\
\hline & Jumlah & $100 \%$ \\
\hline
\end{tabular}

\section{Kata Sehari-hari}

Kata sehari-hari adalah kata yang sering digunakan dalam berkomunikasi dengan orang lain dalam kehidupan sehari-hari. Maksudnya kata yang digunakan tidak memiliki kekhasan tersendiri. Bahasa sehari-hari biasanya besifat mimetik (Riffaterre, 1978). Temuan diksi dalam wacana humor Indonesia di media sosial facebook paling banyak adalah penggunaan katakata yang digunakan dalam kehidupan sehari-hari. Berikut ini data humor Indonesia yang menggunakan kata-kata sehari-hari.

\section{(1) Rapat di Rumah Pak RT Tadi Malam}

Pak RT mengadakan rapat di rumahnya, seluruh warga diundang. Warga: Pak RT, dalam rangka apa rapat ini diadakan? Pak RT: Saya mengadakan rapat ini, dalam rangka menutup botol obat yang baru saya beli kemarin. Warga: Maksudnya apa pak RT? Masa menutup botol obat pakai mengadakan rapat, bikin repot aja! Pak RT: Saya hanya mengikuti petunjuk yang ada di botol ini. Saya khawatir kalo enggak mengikuti petunjuk pabrik obat, sakit saya enggak sembuh. Warga: Petunjuk apa? 
Pak RT: Di botol ini tertulis, *TUTUPLAH BOTOL DENGAN RAPAT*, maka dari itu saya adakan *Rapat ini* Warga: RT edan.... (241-2019)

Data (1) diksi yang digunakan dalam wacana humor tersebut merupakan diksi yang digunakan dalam kehidupan sehari-hari. Penggunaan katakata sehari-hari dalam wacana humor di media sosial bertujuan agar mudah dipahami oleh pembaca dan tidak menimbulkan kerancuan makna atau pesan yang ingin disampaikan. Pembaca dengan membaca humor yang berjudul Rapat di Rumah Pak RT Tadi Malam dapat dengan mudah memahami maksud humor tersebut tanpa harus menginterpretasi kata-kata yang sulit dipahami.

Penggunaan kata sehari-hari dalam wacana humor bukan berarti tidak memiliki daya tarik bagi pembaca. Daya tarik humor tersebut terlihat pada konteks tuturan humor tersebut, yakni maksud tutup rapat botol obat yang dipalsukan dengan tutup botol dengan mengadakan rapat RT. Makna kata rapat dalam KBBI adalah pertemuan (kumpulan) untuk membicarakan sesuatu; sidang; dan majelis. Namun, makna rapat dalam konteks humor tersebut dipalsukan. Kata rapat dalam kalimat tutup rapat botol adalah menutup botol dengan pas dan erat. Jadi, kelucuan humor tersebut terjadi karena diksi rapat yang dipahami pak RT adalah mengadakan pertemuan untuk membicaran sesuatu hal. Padahal yang dimaksud rapat dalam petunjuk botol tersebut adalah menutup botol dengan rapat atau pas dan erat. Berdasarkan hal tersebut menunjukkan bahwa daya kejut kata-kata dalam wacana humor digantikan dengan konteks wacana humor tersebut.

\section{Kata Serapan}

Kata serapan merupakan kata yang diserap, diambil atau dipungut dari bahasa lain, serapan tersebut baik dari bahasa asing maupun bahasa daerah, baik yang sudah mengalami proses adaptasi maupun yang belum mengalami proses adaptasi, dan kata yang sudah dikategorikan dalam bahasa Indonesia. Kata serapan merupakan bagian dari perkembangan dan ciri keuniversalan bahasa (Afjalurrahmansyah, 2018). Kata serapan dalam wacana humor Indonesia cukup banyak ditemukan. Berikut ini data yang menunjukkan kata serapan dalam wacana humor Indonesia.

\section{(2) Sex education}

Anak: mah, ML itu apa?

Mamah: ML itu pekerjaan dua orang dewasa yang saling mencintai. Untuk menuju pekerjaan itu prosesnya sangat panjang. Mereka perlu menikah. Untuk menikah mesti juga berpikir bagaimana membangun rumah tangga, menyiapkan kebutuhan saat punya anak dsb. Seperti mamah ini sudah memenuhi syarat melakukan pekerjaan ML. kok kamu tiba-tiba nanya ML?

Anak: ini botol aqua ada tulisan 600 ML. (17-1-2019)

Data (2) pada wacana humor tersebut menggunakan kata serapan bahasa asing. Adapun kata serapan tersebut adalah berasal dari bahasa Inggris, yakni pada kata Sex education. Penggunaan kata serapan dari bahasa Inggris tersebut memiliki arti pendidikan seksualitas. Penggunaan kata serapan tersebut memiliki daya tarik tersendiri karena menggunakan bahasa asing sedangkan pembaca humor Indonesia menggunakan bahasa Indonesia. Penggunaan kata serapan selain untuk menarik minat pembaca humor juga 
bertujuan mencapai efek estetik terutama dalam memperkuat gagasan dan ide berkaitan dengan pentingnya urgensi pendidikan seksualitas bagi anak-anak. Hal ini sesuai dengan yang dinyatakan Subroto (2013) bahwa diksi dalam sebuah karya sangat penting untuk mengungkapkan ide.

Kata ML adalah singkatan dari kata making love yang berati hubungan seksual. Kata ML dalam konteks wacana humor tersebut menciptakan kelucuan karena kata ML yang ditanyakan anak kepada orang tuanya diterima dengan makna yang berbeda oleh ibunya. Anak menanyakan maksud kata ML dalam botol Aqua yang sebenarnya adalah mililiter, sedangkan ibunya memberikan keterangan ML dalam konteks making love. Dengan demikian ibunya menjelaskan proses supaya seseorang dapat dan boleh melakukan ML padahal yang ditanyakan maksud ML adalah mililiter. Penggunaan kata ML tersebut menjadi pencipta kelucuan humor tersebut.

\section{Kata Sapaan}

Kata sapaan merupakan kata yang digunakan untuk menyebut nama diri seseorang. Dengan kata lain, nama diri seseorang memiliki fungsi sebagai sebutan untuk menunjukkan orang atau sebagai penanda identitas sosial seseorang. Selain itu, kata sapaan bertujuan untuk membangun solidaritas dan kesantunan dalam konteks ini melalui humor (Agus, 2014; H.K, M, L, \& S.K, 2014). Berikut ini data yang menunjukkan kata sapaan dalam humor Indonesia.

(3) Jika Aku Sudah Dewasa $\mathrm{Bu}$ Guru minta para muridnya membuat sebuah karangan pendek. Dengan judul: "Sesudah dewasa nanti aku akan bekerja apa dan menjadi apa?"
Gareng: (Menulis) "Aku sesudah dewasa akan menjadi seorang polisi, membantu warga menangkap orang jahat."

$\mathrm{Bu}$ Guru: (Penilaian) "Angananganmu ini sangat baik, namun kamu besok harus lebih memperhatikan Gareng, teman sebangkumu, ia mengatakan sesudah dewasa ia akan merampok bank." (23-4-2019)

Data (3) terdapat penggunaan diksi nama sapaan, yakni "Bu Guru" dan "Gareng". Penggunaan nama atau sapaan pada seseorang sebagai penanda identitas seseorang. Kata sapaan "Bu Guru" pada wacana humor tersebut sebagai penanda identitas bahwa orang tersebut sebagai seorang guru atau pahlawan tanpa tanda jasa. Apabila dikaitkan dengan status sosial guru dapat digolongkan sebagai kaum priyayi. Kata sapaan dalam kebudayaan Jawa memiliki peran penting sebagai media komunikasi, karena hal tersebut dapat menunjukkan sikap formal atau informal (Susanto, 2014). Penggunaan kata sapaan dalam tindak berbahasa perlu memperhatikan konteks tuturan, apabila konteks tuturan tidak tepat yang terjadi penggunaan kata sapaan terkesan tidak santun (Maros \& John, 2010). Akan tetapi, kata sapaan setiap daerah memiliki makna masing-masing sehingga dimungkinkan adanya perbedaan setiap daerah. Misalnya, penggunaan kata sapaan/salam di Nigeria merupakan bagian budaya dan apabila tidak mematuhinya dianggap sebagai bentuk penyimpangan dalam berkomunikasi (Olaniyi, 2017).

Selain kata sapaan, diksi yang muncul pada wacana humor tersebut adalah penggunaan nama khas, yakni nama "Gareng". Kata sapaan pada data tersebut merujuk pada penanda identitas kelompok, yakni masyarakat Jawa. Hal 
tersebut sesuai yang dinyatakan Rusbiyantoro (2015) bahwa nama diri dapat menunjukkan identitas kelompok. Penggunaan nama "Gareng" menjadi khas karena nama tersebut merupakan nama salah satu tokoh pewayangan. Nama "Gareng" dalam cerita pewayangan sarat akan makna yang baik untuk diteladani. "Gareng" dalam tokoh pewayangan merupakan orang yang berkaki pincang yang memiliki makna filosofi orang yang hati-hati dalam bertutur kata, bersikap, dan bertindak. Hal ini berbeda dengan peran "Gareng" dalam wacana humor tersebut yang diidentikan dengan seorang penjahat sehingga berbeda dengan makna filosofi dalam tokoh pewayangan.

Kelucuan dalam konteks humor tersebut adalah ketika "Bu Guru" yang sedang menanyakan cita-cita kepada murid-muridnya. Salah seorang murid bercita-cita akan menjadi polisi yang bertugas menjaga keamanan dan ketertiban masyarakat. Akan tetapi, murid yang bernama "Gareng" yang duduk sebangku dengan murid yang bercita-cita menjadi polisi bercita-cita akan merampok bank. Artinya teman sebangkunya ketika sekolah yang akan berbuat ketidaktertiban di masyarakat. Dengan demikian ketika keduanya dewasa dan mencapai cita-citanya "Gareng" adalah orang pertama yang akan ditangkap polisi, yakni teman sebangkunya.

\section{Kata Konotatif}

Kata konotatif merupakan kata yang memiliki makna komunikatif yang terlepas dari makna harfiahnya yang di dasarkan pada perasaan pengarang tentang sesuatu yang sedang dibahasakan. Makna konotatif adalah makna sugestif dari sebuah kata yang tidak merujuk pada makna arti dalam kamus (Ruiz et al., 2018). Berikut ini humor yang menggunakan kata konotatif.

(4) Kecemasan

"Kriiing..." telepon berdering. "YUDI... terpaksa kamu harus pulang sekarang juga!" Begitu suara kakakku Andi di dalam teleponnya. Terus telepon ditutup. Aku menjadi cemas? Dalam hatiku berfirasat buruk, jantung mendadak berdegup keras, pikiran melayang tidak menentu. Serasa berada di kampung halaman selama menyetir mobil, pasti ini ada hal yang sangat penting kenapa buru-buru aku disuruh pulang. Setelah sampai rumah sudah terpasang "Bendera Kuning" jantung serasa copot, enggak salah firasatku ini. Orang-orang berseliweran melakukan tugasnya masing-masing, kursi semua sudah dikeluarkan, malah didepan rumah sudah terpasang tenda pula. Tenggorokan serasa tercekak. Ibuku didepan pintu berdiri, lalu aku mencium tangan Ibuku serta memeluknya. "A...a...ada apa ini mak...?" enggak keluar suaraku karena tenggorokan sudah penuh dengan bahan tangisan. "Ayah kamu Ded" Mak enggak selesai bicaranya. "Ayah...? Ayah kenapa Mak...?" Air mata sudah tidak bisa dibendung. "Ayah kamu masuk GOLKAR!" Jangan serius-serius amat nanti stroke (18-10-2019)

Data (4) tersebut terdapat penggunaan kata-kata yang memiliki makna konotatif. Hal ini terlihat pada penggunaan kata "pikiran melayang". Penggunaan diksi pikiran melayang akan menimbulkan interpretasi yang berbedabeda, ada yang mengartikan sebagai sebuah suka cita karena bahagia hadirnya seorang kekasih, tetapi dicermati makna kata pikiran melayang pada wacana humor tersebut merupakan 
bentuk kecemasan seorang anak karena mendapatkan telepon dari kakak untuk segera pulang ke rumah. Apabila seseorang mendapat telepon mendadak dan diminta untuk segera pulang tanpa ada informasi yang jelas tentu akan cemas seperti "pikiran melayang" tidak menentu. Diksi tersebut memiliki daya untuk persuasif mengajak pembaca untuk berimajinasi.

Selain itu, diksi konotatif juga terdapat pada penggunaan kata "Bendera Kuning". Makna kata tersebut di wilayah tertentu dijadikan sebagai simbol kematian atau bermakna adanya kematian seseorang. "Bendera Kuning" pada wacana humor tersebut memiliki makna sebuah bendera partai politik, yakni Golongan Berkarya (Golkar). Penggunaan kata tersebut mampu mengecoh pemahaman pembaca bahwa bendera kuning di depan rumah dimaknai sebagai adanya peristiwa kematian. Hal tersebut semakin diperkuat dengan konteks Yudi diminta untuk segera pulang ke rumah.

Kata konotatif yang lain pada wacana humor tersebut adalah penggunaan diksi "jantung copot". Frasa "jantung serasa copot" dapat menimbulkan pemahaman yang beragam dan dimungkinkan menimbulkan makna yang berbeda dari makna yang sebenarnya. Adapun frasa "jantung serasa copot" pada wacana tersebut adalah rasa kaget karena dugaan yang buruk telah terbukti terjadi pada seseorang yang disayanginya. Apabila dugaan yang buruk terjadi pada orang yang disayanginya terbukti dan terjadi maka orang tersebut tentu akan kaget seperti jantung serasa copot.

\section{Kata Konkret}

Kata konkret merupakan kata yang referennya dapat dilihat atau diindera secara langsung oleh panca indera.
Penggunaan kata konkret dalam sebuah karya bertujuan untuk menyajikan gambaran yang hidup dalam pikiran pembaca melebihi makna kata-kata tersebut (Irfariati, 2017). Dengan demikian penggunaan kata konkret dalam sebuah karya akan dapat mempermudah pemahaman pembaca (De Groot \& Keijzer, 2000; De Groot, 2006; Mestres-Missé, Münte, \& Rodriguez-Fornells, 2009; Loiselle et al., 2012' Palmer, MacGregor, \& Havelka, 2013). Berikut ini kata konkret dalam wacana humor di media sosial facebook.

(5) Bisa dibilang senjata makan tuan. "Penyebab Rambut Uban" Ada seorang anak bertanya kepada ibunya yang sedang sibuk memasak di dapur. Anak: "Bu... Mengapa rambut ibu ada yang putih?" Ibu: "Karena kamu nakal sekali. Suka enggak nurut sama ibu. Sering bikin ibu susah". Anak: (Dengan lugu) "Oo...Maafinyaa Bu. Saya enggak mau kalau rambut ibu kayak nenek gara-gara saya." (Sambil memperlihatkan foto neneknya). Ibu: "Ha........?"

(14-5-2019)

Data (5) merupakan wacana humor yang mengandung kata-kata konkret, yakni "rambut uban". Penggunaan diksi "rambut uban" dapat dikatakan kata konkret karena referen kata tersebut berupa objek yang dapat diamati oleh panca indera. Hal ini sesuai dengan yang dinyatakan Sabsevitz, Medler, Seidenberg, \& Binder, 2005; Wang, Conder, Blitzer, \& Shinkareva, 2010; Cousins, York, Bauer, \& Grossman, 2016) bahwa kata-kata konkret berkaitan dengan fitur visual, dan objek. Penggunaan kata konkret dalam wacana humor tersebut mampu menyajikan informasi yang tepat kepada pembaca sehingga tidak menimbulkan salah paham. Melalui diksi "rambut uban" 
pembaca akan langsung paham bahwa yang dimaksud adalah rambut yang beruban. Dengan demikian penggunaan kata konkret dalam wacana humor di media sosial facebook bertujuan menghindari salah paham atau interpretasi pembaca.

Penggunaan frasa "rambut uban" dalam wacana humor tersebut menjadi pencipta kelucuan karena "rambut uban" pada wacana humor tersebut dimaksudkan untuk mendidik anak supaya tidak nakal. Anak yang begitu lugu meminta maaf kepada ibunya karena dia tidak menginginkan rambut ibunya menjadi putih seperti rambut neneknya yang sudah putih semua seperti yang ada di foto. Kelucuannya adalah karena rambut uban yang dijadikan alasan untuk mendidik anak supaya tidak nakal dan menurut pada orang tua tidak berhasil dan anak malah menyindir dengan menunjukkan foto neneknya yang rambunya sudah beruban atau putih.

\section{Kata Vulgar}

Kata vulgar merupakan kata-kata tabu yang seharusnya dalam tindak komunikasi formal dihindari atau tidak digunakan. Kata vulgar tidak dapat dikatakan sebagai yang hanya memiliki makna negatif akan tetapi, terkadang kata vulgar juga menunjukkan hubungan yang akrab atau intim (Sholihatin, 2013). Bahkan penggunaan kata-kata vulgar dalam media sosial sudah menjadi kebiasaan dan tidak menimbulkan masalah (Maros \& Rosli, 2017). Berkaitan dengan rasa bahasa dan kesantunan bahasa tidak semata-mata hanya dilihat dari aspek linguistik, akan tetapi juga perlu melihat bahasa berdasarkan konteks penggunaan kata tersebut. Kata vulgar dalam wacana humor Indonesia di media sosial juga ditemukan, akan tetapi tidak terlalu banyak. Berikut ini contoh humor yang menggunakan kata vulgar.

(6) Cerita singkat

Suatu hari saya sedang berkendara naik motor pakai helm. Di tengah perjalanan ada jalan baru yang baru selesai dipasang box culvert. Ditengah-tengah dipasang drum yang dicor lantas dipasang papan bertuliskan "BUNTU MAS/MBAK". Tetapi melihat tidak sedikit pengguna jalan yang lewat, akhirnya aku mengikuti (biasa wong Indonesia)... tidak lama kemudian pengguna yang tadi lewat balik kucing... Oh ternyata benar tulisan tadi, Akhirnya aku pun ikut balik. Sampai dekat papan tadi ternyata dibaliknya ada tulisan lagi. Isengiseng aku baca sambil tetap naik motor pelan-pelan. "WIS DIKANDANI BUNTU NEKAT AE...GuoblogAnceneJancuk!!!” (71-2019)

Data (6) merupakan wacana humor yang mendayagunakan kata-kata vulgar. Kata vulgar dalam wacana humor tersebut terlihat pada penggunaan kata Guoblog Ancene Jancuk (Bodoh memang jancuk). Penggunaan kata-kata tersebut dilatarbelakangi karena emosi kepada pengendara yang tidak mematuhi rambu-rambu jalan. Kata vulgar biasanya diucapkan karena emosi seorang penutur yang tidak bisa dikendalikan (Setiawaty et al., 2018). Namun, apabila dicermati penggunaan kata vulgar tersebut sudah menjadi suatu kebiasaan dan sudah ada kesepakatan antara penulis dan pembaca sehingga pembaca tidak merasa bahwa kata-kata tersebut sebagai kata vulgar. Akan tetapi, yang menjadi penting adalah apabila digunakan dalam situasi formal kata tersebut kurang dan bahkan tidak santun.

Kelucuan pada wacana humor tersebut terlihat dari penggunaan kata 
vulgar. Cerita singkat tentang seorang pengendara sepeda motor yang mengetahui bahwa jalan buntu, tetapi tetap nekat. Setelah kembali ada katakata wis dikandani buntu nekat ae... guoblog ancene jancuk (sudah dikasih tau tetap saja nekat, bodoh memang jancuk). Ungkapan tersebut memang sudah disediakan sebelumnya sehingga bagi pengedara yang ngeyel atau tidak patuh bahwa jalan itu buntuakan merasa malu karena membaca ungkapan wis dikandani buntu nekat ae.. guoblog ancene jancuk (sudah dikasih tau tetap saja nekat, bodoh memang jancuk) yang memiliki maksud bahwa sang pengendara adalah orang yang ngeyel atau tidak mau mendengarkan nasihat orang lain.

\section{PENUTUP}

Berdasarkan hasil dan pembahasan di atas dapat disimpulkan bahwa penggunaan diksi dalam wacana humor Indonesia meliputi (1) diksi sehari-hari; (2) kata serapan (Jawa dan Inggris); (3) kata sapaan; (4) kata konotatif; (5) kata konkret; dan (6) kata vulgar. Diksi sehari-hari dalam wacana humor Indonesia merupakan diksi yang paling banyak ditemukan. Temuan ini menunjukkan bahwa diksi keseharian dalam wacana humor berfungsi untuk menyampaikan pesan kepada mitra wicara. Adapun daya kejut dalam wacana humor terletak pada konteks wacana humor yang menggunakan diksidiksi tersebut yang menimbulkan kontradiktif sehingga memunculkan kesan humor.

\section{UCAPAN TERIMA KASIH}

Terima kasih kepada Kementerian Riset Teknologi Pendidikan tinggi yang telah mendanai penelitian ini. Terima kasih kepada mitra bestari yang telah memberikan komentar dan masukan terhadap artikel ini sehingga layak untuk dipublikasikan.

\section{DAFTAR PUSTAKA}

Afjalurrahmansyah. (2018). Bahasa Arab dalam bahasa Indonesia (analisis kritis terhadap perubahan makna kata serapan Bahasa Arab). Jurnal Diwan Vol., 4(1), 44-57. https://doi.org/https://doi.org/10.2 4252/diwan.v4i1.4670

Agus, N. (2014). Bentuk sapaan bahasa Bugis dalam konteks pragmatik gender. SAWERIGADING, 20(1), $1-13$. https://doi.org/http://dx.doi.org/1 $0.26499 /$ sawer.v20i1.12

Al-Ma'ruf, A. I. (2012). Stilistika teori, metode, dan aplikasi pengkajian estetika bahasa. Cakra Books.

Bhakti, I. G., Putra, V., \& Noak, P. A. (2018). Gerakan sosial politik meme pada media sosial Instagram untuk Bali tolak reklamasi. E-Jurnal Politika, 1(1), 1-12. https://ojs.unud.ac.id/index.php/p olitika/article/view/37812

Borghesani, V., \& Piazza, M. (2017). The neuro-cognitive representations of symbols: The case of concrete words. Neuropsychologia, 105, 4-17. https://doi.org/10.1016/j.neurops ychologia.2017.06.026

Bowman, N. D., \& Hallett, J. S. (2017). Squid or chalkie? The role of self-identity and Selective perception in processing tendentious "Hillbilly" humor. Ohio Ommunication Journal, 55(February), 16-28. https://scholars.ttu.edu/en/publica tions/squid-or-chalkie-the-roleof-self-identity-and-selectivepercepti 
Budiyanto, D. (2009). Penyimpangan implikatur percakapan dalam humor-humor Gus Dur. Litera, 8(2), $\quad$ 105-117. https://doi.org/https://doi.org/10.2 18/ltr.v8i2.1206

Cousins, K. A. Q., York, C., Bauer, L., \& Grossman, M. (2016). Cognitive and anatomic double dissociation in the representation of concrete and abstract words in semantic variant and behavioral variant frontotemporal degeneration. Neuropsychologia, 84 , 244-251. https://doi.org/10.1016/j.neurops ychologia.2016.02.025

Creswell, J. W. (2014). Research design: Qualitative, quantitative, and mixed methods approaches. United States of America.

Dai, J. (2018). Interpretation of humor between Chinese and Americans from the angle of culture in Friends. Journal of Language Teaching and Research, 9(6), 1356-1361.

http://www.academypublication.c om/issues2/j1tr/vol09/06/27.pdf

De Groot, A. M. B. (2006). Effects of stimulus characteristics and background music on foreign language vocabulary learning and forgetting. Language Learning, 56(3), 463-506. https://doi.org/https://doi.org/10.1 111/j.1467-9922.2006.00374.x

De Groot, A. M. B., \& Keijzer, R. (2000). What is hard to learn is easy to forget: The roles of word concreteness, cognate status, and word frequency in foreign language vocabulary learning and forgetting. Language Learning, 50(1), 1-56. https://doi.org/https://doi.org/10.1 111/0023-8333.00110
Deen, P. (2018). Senses of humor as political Virtues. Metaphilosophy, 49(3), 371-387. https://doi.org/10.1111/meta.122 97

Fatoni, N. R. (2017). Kekhasan diksi Valentino Simanjuntak pada piala presiden 2017. Adabiyyāt: J urnal Bahasa Dan Sastra, I(2), 223247.

https://doi.org/https://doi.org/10.1 4421/ajbs.2017.01205

H.K, T., M, L, T., \& S.K, T. (2014). Beyond ' greeting ' and ' thanking ': Politeness in job interviews. 3L: The Southeast Asian Journal of English Language Studies, 22(3), 171184.

https://doi.org/http://doi.org/10.1 7576/3L-2016-2203-12

Irfariati. (2017). Diksi dalam retorika Agus Harimurti Yudhoyono sebagai calon gubernur DKI. Metalingua, 15(1), 41-51. https://doi.org/http://dx.doi.org/1 0.26499/metalingua.v15i1.153

Keraf, G. (1987). Diksi dan gaya bahasa. Gramedia.

Loiselle, M., Rouleau, I., Nguyen, D. K., Dubeau, F., Macoir, J., Whatmough, C., Lepore, F., \& Joubert, S. (2012). Comprehension of concrete and abstract words in patients with selective anterior temporal lobe resection and in patients with selective amygdalohippocampectomy.

Neuropsychologia, 50(5), 630639.

https://doi.org/10.1016/j.neurops ychologia.2011.12.023 
Maros, M., \& John, A. (2010). Pola sapaan pelajar lelaki dan perempuan di sebuah institusi pengajian tinggi: Satu kajian sosiopragmatik. GEMA OnlineTM Journal of Language Studies, 10(2), 77-96. https://ejournal.ukm.my/gema/art icle/view/110/101

Maros, M., \& Rosli, L. (2017). Politeness strategies in Twitter updates of female english language studies Malaysian undergraduates. $\quad 3 \mathrm{~L}$ : $\quad$ The Southeast Asian Journal of English Language Studies -, 23(1), 132-149. https://doi.org/http://doi.org/10.1 7576/3L-2017-2301-10

Politeness

Menninghaus, W., Wagner, V., Wassiliwizky, E., Jacobsen, T., \& Knoop, C. A. (2017). The emotional and aesthetic powers of parallelistic diction. Poetics, 63(2016), 47-59. https://doi.org/10.1016/j.poetic.2 016.12 .001

Mestres-Missé, A., Münte, T. F., \& Rodriguez-Fornells, A. (2009). Functional neuroanatomy of contextual acquisition of concrete and abstract words. Journal of Cognitive Neuroscience, 21(11), 2154-2171.

https://doi.org/10.1162/jocn.2008 .21171

Olaniyi, K. (2017). Politeness principle and ilorin greetings in Nigeria: A sociolinguistic study. International Journal of Society, Culture \& Language, 5(1), 5867.

http://www.ijscl.net/article_2493 1.html
Palmer, S. D., MacGregor, L. J., \& Havelka, J. (2013). Concreteness effects in single-meaning, multimeaning and newly acquired words. Brain Research, 1538, 135-150. https://doi.org/10.1016/j.brainres. 2013.09.015

Pradopo, R. D. (1993). Pengkajian Puisi. Gadjah Mada University Press.

Riffaterre, M. (1978). Semiotics of poetry. Indiana University Press.

Rochmawati, D. (2017). Pragmatic and rhetorical strategies in the English-Written Jokes. Indonesian Journal of Applied Linguistics, $\quad 7(1), \quad 149$. https://doi.org/10.17509/ijal.v7i1. 6868

Ruiz, T., Arroyo, R., Casquero, D., Serna, A., \& Mars, L. (2018). Connotative meaning of travel modes and activity-travel behavior. Transportation Research Procedia, 33, 379-385. https://doi.org/10.1016/j.trpro.20 18.11 .004

Rusbiyantoro, W. (2015). Kesantunan melalui pemilihan kata sapaan dalam bahasa Melayu Kutai: Suatu kajian pragmatik. Seminar Nasional Prasasti (Pragmatik: Sastra Dan Linguistik), 275-283. https://doi.org/https://doi.org/10.2 0961/pras.v0i0.514

Sabsevitz, D. S., Medler, D. A., Seidenberg, M., \& Binder, J. R. (2005). Modulation of the semantic system by word imageability. Neuroimage, 27(1), 188-200. https://doi.org/10.1016/j.neuroim age.2005.04.012 
Saleh, R. (2017). Bentuk sapaan kekerabatan dalam bahasa Banjar di Tembilahan, Riau. Madah, $8(1)$, 19-34. https://doi.org/https://doi.org/10.3 1503/madah.v8i1.74

Saputro, S. (2016). Humor terkait Mu' Ammar Al-Qazafi (analisis pragmatik). Adabiyyāt, $X V(2)$, 198-225.

https://doi.org/https://doi.org/10.1 4421/ajbs.2016.15205

Sariah, S. (2018). Metafora dalam iklan mobil bekas di situs daring Olx. Aksara, $29(1), \quad 117$. https://doi.org/10.29255/aksara.v 29i1.105.117-130

Setiawaty, R., Murdiyanto, D. P. L., \& Amin, M. K. (2018). Pengidentifikasian dan pengkreasian ungkapan vulgar pada komentar akun facebook Presiden Joko Widodo sebagai inovasi bahan ajar. Prosiding Seminar Nasional Geotik II, 2838.

https://publikasiilmiah.ums.ac.id/ handle/11617/9781

Setiyanto, E. (2018). Humor dalam rambu lalu lintas. Widyaparwa, 46(2), 99-111. https://doi.org/https://doi.org/10.2 6499/wdprw.v46i2.206

Shaumia, D. (2019). Makna konotatif dalam teks ulasan cerpen dalam mata kuliah semantik mahasiswa bahasa Indonesia semester III Universitas Muhammad Yamin Solok tahun pelajaran 2017/2018. Inovasi Pendidikan, 6(1), 1-6. https://jurnal.umsb.ac.id/index.ph p/inovasipendidikan/article/view/ 1564
Sholihatin, E. (2013). Apakah pisuhan selalu bermakna negatif ?: Fungsi pisuhan dalam masyarakat Arek dan masyarakat Mataraman. Mozaik Humaniora, 13(2), 158167. https://doi.org/http://dx.doi.org/1 0.20473/mh.v13i2.3843

Subet, M. F., \& Zaid, M. (2018). Makna denotatif dan konotatif dalam slanga pelacur. MALTESAS Multi-Disciplinary Research Journal (MIRJO), 3(April), 2943. https://osf.io/wegc7/

Subroto, D. E. (2013). Kajian stilistika teks bahasa Pedalangan Wayang Purwo gaya Surakarta. Bahasa Dan Seni, 4l(2), 143-158. http://journal2.um.ac.id/index.ph $\mathrm{p} / \mathrm{jbs} /$ article/view/105

Sudaryanto. (2015). Metode dan aneka teknik analisis bahasa pengantar penelitian wahana kebudayaan secara linguistis. Sanata Dharma University Press.

Susanto, D. (2014). The pragmatic meanings of address terms sampeyan and anda. Indonesian Journal of Applied Linguistics, 4(1), 140. https://doi.org/10.17509/ijal.v4i1. 606

Suwija, I. N. (2018). Sistem sapaan bahasa Bali menurut hubungan kekerabatan. Sosiohumaniora Jurnal Ilmu-Ilmu Sosial Dan Humaniora, 20(2), 115-121. https://doi.org/https://doi.org/10.2 4198/sosiohumaniora.v20i2.1673 1

Tojo, H., \& Takagi, A. (2017). Trends in qualitative research in three major language teaching and learning journals, 2006-2015. International Journal of English Language Teaching, 4(1), 37. https://doi.org/10.5430/ijelt.v4n1 p37 
Ucan, B. (2018). The suicide shop as an example of dark huor. The Journal of International Social Research, 11(61), 537-542. https://avesis.yildiz.edu.tr/yayin/e 080763f-fe32-4071-acd8a9a8926922b7/the-suicide-shopas-an-example-of-dark-humor

Utama, F. R., \& Arief, E. (2012). Kata sapaan dalam bahasa Minangkabau di Kenagarian Tuik IV Koto Mudiak Batang Kapas Kabupaten Pesisir Selatan. Jurnal Pendidikan Bahasa Dan Sastra Indonesia, 1(1), 646-653. http://ejournal.unp.ac.id/index.ph p/pbs/article/view/1379

Wang, J., Conder, J. A., Blitzer, D. N., \& Shinkareva, S. V. (2010). Neural representation of abstract and concrete concepts: A meta analysis of neuroimaging studies. Human Brain Mapping, 31(10), 1459-1468. https://doi.org/10.1002/hbm.2095 0
Wijana, I. D. P. (2018). Exploitation of pragmatic aspects in Indonesian humorous discourses. Journal of Language and Literature, 17(2), 108-115. https://doi.org/10.24071/joll/2017 .170201

Wurianto, A. B. (2015). Kata serapan bahasa Sanskerta dalam bahasa Indonesia. KEMBARA: Jurnal Keilmuan Bahasa, Sastra, Dan Pengajarannya, 1(1), 125-134. https://doi.org/https://doi.org/10.2 2219/kembara.v1i2.2610

Zurqoni, Z., Retnawati, H., Apino, E., \& Anazifa, R. D. (2019). Impact of Character Education Implementation: a Goal-Free Evaluation. Problems of Education in the 21st Century, 76(6), 881-899. https://doi.org/10.33225/pec/18.7 6.881 